IVAN BASIĆ

UDC: $930.2: 003.071$

Odsjek za povijest

Filozofski fakultet Sveučilišta u Splitu

Split, Hrvatska

\title{
POSTKONZULAT I PARS IMPERII NA NATPISU SVEĆENIKA ANASTAZIJA IZ SLANOG ( $A D$ CIL III 14623)
}

\begin{abstract}
Latinski natpis na sarkofagu svećenika Anastazija iz Slanog u dubrovačkom primorju (CIL III, $14623=$ ILCV $1174=$ AE 1902, 208) vremenski je određen datumom (11. ožujka 462.), indikcijom (15. indikcija, od 1. rujna 461. do 31. kolovoza 462.) i postkonzularnom datacijom (konzul Flavije Severin, od 1. siječnja do 31. prosinca 461.). Prozopografija Anastazijeva epitafa nije dublje istraživana, niti je uočena važnost ovog natpisa za konzularne datacije kao epigrafski pokazatelj političke pripadnosti Dalmacije u kasnoj antici. Utvrđuje se da natpis pripada natpisima nastalima u razdoblju bilateralnog ignoriranja konzula obaju Carstava. Postkonzularna datacija je zapadnog tipa (konzul Zapadnoga Rimskog Carstva za prethodnu godinu); ignorirani su istočni konzul za 461. (Dagalaif) i oba konzula za 462. godinu (Libije Sever i Lav I.). Temeljem triju natpisa iz Istočnog Carstva (Solun, Alahan u Izauriji) i drugih izvora opovrgava se da u Dalmaciji 462. nije bilo poznato ime istočnog konzula iz 461. godine, Dagalaifa. Time se ukazuje da je s Anastazijeva epitafa ciljano ispušteno Dagalaifovo ime, odnosno da je Dalmacija 462. službeno priznavala samo zapadnorimske konzule, tj. da navodna predaja te provincije Istočnom Carstvu 437. nije imala učinka na formalnopravnu pripadnost Zapadu.
\end{abstract}

Ranokršćanska epigrafija istočne obale Jadrana, kvantitativno brojna i kvalitativno vrsna, posebno je vrijedna kada sadrži informacije što mogu dodatno osvijetliti društveni milje i šire okolnosti u kojima se u kamen uklesani tekstovi pojavljuju. Sadržaj tih natpisa osobito je dragocjen ukoliko se u njima zapazi kakav detalj, pojedinost kojom se natpis ističe u korpusu općih mjesta i uvelike standardiziranog diskursa kasnoantičke i ranokršćanske epigrafije. Nerijetko ti novouočeni epigrafski podaci mogu baciti sasvim novo svjetlo na čitav spektar arheoloških, kulturnopovijesnih, onomastičkih i lingvističkih pitanja, dosad neriješenih ili nepotpuno riješenih. Premda još uvijek ne raspolažemo korpusom ranokršćanskih natpisa cijele rimske Dalmacije, dominantna većina njih sabrana je nedavno u zborniku ranokršćanskih natpisa salonitanske regije (katalogizirano ukupno 825 ranokršćanskih natpisa, 
od čega 742 latinska i 83 grčka), ${ }^{1}$ gdje su sustavno proučena njihova paleografska svojstva, pružajući na taj način i sigurnija uporišta zaključcima o kronologiji epigrafske produkcije u ostatku Dalmacije. Uz to, analizirane su grčke i latinske nadgrobne formule u kršćanskoj epigrafiji, konzularna $\mathrm{i}$ indikcionalna datacija, demografska pitanja, prozopografija, nadgrobne formule za zaštitu grobnice, društvena struktura, urbanističko i političko funkcioniranje Salone, migracije, govorni jezici, obrtne korporacije i udruge, vojnička epigrafija, crkveno ustrojstvo i hijerarhija, kult mučenika i svetaca, vulgarni latinitet, itd. Korpus Salona $I V$ prvorazredna je osnova za obradu preostaloga epigrafičkog materijala u provinciji, iz više aspekata, disciplinâ i znanosti.

U gotovo nepreglednom broju pitanja koja može otvoriti neki natpis, ponekad i nevelik detalj može pridonijeti rješavanju znatnijih znanstvenih problema. S pravom je, primjerice, već odavno u literaturi primijećeno da podaci iz konzularne datacije u epigrafiji mogu poslužiti kao kriterij za određivanje vrhovne političke vlasti nad zemljom u kojoj je natpis nastao. ${ }^{2}$ Ta je konstatacija utoliko važnija što su kameni spomenici, kako je poznato, izvor koji ne podliježe sukcesivnim promjenama kakve su česte npr. u drugim pisanim materijalima (naknadne korekcije, greške prepisivača, itd.). Oni vjerno odražavaju namjere sastavljača, dajući time sliku društvenoga stanja - lokalnog, regionalnog ili provincijskog $-\mathrm{u}$ trenutku nastanka natpisa.

Broj konzula u epigrafskoj dataciji ovisi o legalnosti njihova obnašanja dužnosti tj. uzajamnom (ne)priznavanju tog i takvog stanja, dok je redoslijed konzula na natpisu ovisan o njihovu društveno-političkom statusu (car ili carev srodnik, civil, bivši konzul itd.). ${ }^{3}$ Općenito uzevši, poslije podjele Carstva 395. godine, javlja se tendencija da svaka polovina države na prvom mjestu donosi svoga konzula (consul prior). Razlog tome nalazi se i u činjenici što od 411. godine nadalje konzuli više nisu nominirani i proglašavani simultano, već odvojeno za svaku polovicu Carstva. ${ }^{4} \mathrm{U}$ slučajevima kada pojedini od konzula ne bi bio priznat, u dijelu Carstva koji ga je odbijao na natpisima se redovito izostavljalo njegovo ime, a zadržavalo ime konzula imenovanog od strane vladara tog dijela Carstva. ${ }^{5}$ To znači da konzularne datacije iz godinâ obostranog nepriznavanja konzula - i to one navedene na cjelovito sačuvanim, autentičnim natpisima neupitne provenijencije - predstavljaju jasan

${ }^{1}$ Salona IV, 1-2 (2010). Od toga je 49 dosad neobjavljenih natpisa (45 latinskih i 4 grčka). Uz 825 kataloških jedinica, objavljeno je još 467 fragmentarno sačuvanih natpisa (451 latinski i 16 grčkih, 124 neobjavljena). U čitavu korpusu je, dakle, objavljen ukupno 1301 natpis.

${ }^{2} \mathrm{~S}$ ovog aspekta, pomoću konzularnih datacija na epigrafičkoj građi, prvi su suverenitet nad Dalmacijom istraživali Ljubić (1875): 63 i Jung (1887): 186, bilj. 2, na što se zatim oslonio Bury (1923): 221, bilj. 2. Vidi i opaske u Rogošić (1962): 126. Usp. također Wilkes (1972): 388 i bilj. 35.

${ }^{3}$ CLRE (1987): 63-65; Meimaris et al. (1992): 341-342.

${ }^{4}$ CLRE (1987): 64; Meimaris et al. (1992): 349.

${ }^{5}$ CLRE (1987): 25. 
kriterij u zaključivanju o političkoj pripadnosti dotičnog ozemlja jednoj ili drugoj polovini rimske države. Ukoliko je, dakle, natpis datiran parom konzula, indikativan je consul prior; ukoliko je datiran samo jednim konzulom, taj u pravilu pripada dijelu Carstva u kojem se natpis nalazi.

$\mathrm{Za}$ ustanovljavanje datuma kada se u odgovarajućoj provinciji doznalo ime novih konzula izvrsno mogu poslužiti tzv. postkonzularne datacije, tj. formule koje se - u nedostatku svježijih informacija - pozivaju na eponimne konzule prethodne godine. Najjednostavnije rečeno: dok god se u novoj godini na natpisnoj građi koristi postkonzulat, to upućuje da novoproglašeni konzuli još uvijek nisu bili poznati; kada se pak njihova imena počinju javljati, daju siguran oslonac za utvrđivanje koliko je dug bio vremenski raspon kašnjenja (računajući od 1. siječnja). S velikom se sigurnošću uzima da su postkonzularne datacije iz prva dva mjeseca bilo koje godine rezultat tog kašnjenja (pod uvjetom da na istoj lokaciji nema nikakvih drugih svjedočanstava kako su imena novih konzula već pristigla, te bila ciljano potisnuta). ${ }^{6}$ Kako je nepouzdanost $\mathrm{u}$ transmisiji konzulskih imena prema provincijama s vremenom rasla, sve učestalija je bila pojava dugotrajnih kašnjenja i sve dužih intervala datiranja po postkonzulatu; dominantna je u V. stoljeću, da bi kulminirala u VI. stoljeću, kada se susreću i takve anomalije poput postkonzulata u višestrukim iteracijama, čak regionalnih postkonzularnih erâ.

Pojava postkonzularne datacije, međutim, može biti i posljedica specifičnoga društveno-političkog trenutka: imena novih konzula poznata su sastavljaču natpisa, no on ih izbjegava upotrijebiti kako bi se distancirao od mogućih neželjenih političkih posljedica (novi konzuli su nepriznati, ili postoji više pretendenata različitoga stupnja legitimiteta, s nejasnom i nepredvidljivom budućnošću). U takvim situacijama, oportunije je bilo zabilježiti imena najrecentnijeg nespornog konzulskog para, obično onoga iz prethodne godine, negoli riskirati s imenima koja će možda morati biti uklonjena. ${ }^{\top}$ Otud potječe dobar dio postkonzularnih datacija koje su zašle duboko u novu kalendarsku godinu, često i u sasvim kasne mjesece.

S teritorija Dalmacije potječe nekolicina natpisa s konzularnim ili postkonzularnim datacijama koji posjeduju izrazitu heurističku vrijednost u ovom pogledu. U nedavno objavljenom radu o novouočenom grčkom natpisu Sirijca Izaka s otoka Lopuda (452. g. $)^{8}$ upozorili smo da

${ }^{6}$ CLRE (1987): 65.

${ }^{7}$ CLRE (1987): 65-66.

${ }^{8}$ Basić-Zeman (2017). Objavljen je grčki epitaf s ranokršćanskog sarkofaga pronađenog u crkvi Sv. Ilije na Lopudu. Donesen je opis spomenika, čitanje i datacija epitafa, epigrafička, antroponimijska i povijesna analiza, uz arheološko-topografski kontekst nalaza. Identificirano je pokojnikovo ime (Izak) i porijeklo (sjeverna Sirija ili Mala Azija) te ustanovljena datacija (17. listopad 452.). Posebno je analiziran spomen zapadnorimskog konzula u formuli datacije, te utvrđeno da je riječ o prvoj pouzdanoj epigrafskoj potvrdi pripadnosti Dalmacije zapadnom dijelu Rimskog Carstva u V. st. Budući da je u navedenom radu in extenso izložena sva argumentacija i relevantna literatura, ovdje se ti podaci neće opetovati osim u mjeri u kojoj je nužno za osvrt na 
je natpis datiran isključivo zapadnorimskim konzulom; kako se radi o godini u kojoj se istočni i zapadni konzul obostrano nisu priznavali, lopudski natpis registrira oficijelni stav u provinciji Dalmaciji, kao dijelu Zapadnog Carstva, o tome tko je 452. godine bio eponimni konzul, odnosno gdje se nalazila nadležna vrhovna vlast. Epitafu Izaka sina Antiohova, oblikom i sadržajem njegove kronologijske formule, pripada izuzetno mjesto u kasnoj rimskodobnoj epigrafiji. Razriješen, objavljen i komentiran, tekst Izakova natpisa pružio je rješenja s dalekosežnim povijesnim konzekvencijama. Izakov je epitaf nedvojbeno jedan od najvrijednijih i najsadržajnijih dalmatinskih natpisa iz kasne antike, $i$ to ponajprije kao izdašan povijesni izvor, ali i po tome što njegov tekst unatoč svojoj sažetosti - predstavlja dosad najkompletniji, podacima najobilniji epigrafski spomenik na grčkom jeziku s ozemlja ranokršćanske Dalmacije, u kojem su na izvanredan način izražene njegove paleografske, kronološke i prozopografske odlike. ${ }^{9}$ Izakov epitaf prvi je natpis iz Dalmacije koji neosporno potječe iz godine bilateralno osporenih konzula; epigrafska je potvrda zapadnog tipa konzularne datacije. Time je opovrgnuta teorija o prepuštanju Dalmacije istočnom dijelu Carstva 437. godine. Jednako je sažet i odavna poznati latinski epitaf svećenika Anastazija na njegovu sarkofagu iz Slanog u dubrovačkom primorju. Iako je taj natpis objavljen u nekoliko navrata - prvi put prije više od jednog stoljeća - on, osim odavna poznatih povijesnih podataka, sadrži i jednu dosad neuočenu pojedinost relevantnu za kasnoantičku povijest Dalmacije. Ovdje ćemo na nju pokušati ukazati, obrazložiti ju i kontekstualizirati.

natpis iz Slanog. Kako ondje nije bilo prostora za cjelovitu analizu slanskog natpisa (iako je njegova potpuna sukladnost lopudskom natpisu već tada ustanovljena - v. Basić-Zeman (2017): bilj. 111), obrađen je u posebnom radu koji se ovdje podastire.

${ }^{9}$ Natpis je na grčkom jeziku, što je vrlo rijetko izvan salonitanskog teritorija (a i ondje ponajviše ograničeno na inozemce). Ta okolnost upućuje da pokojnik nije bio domicilni stanovnik, već došljak. Prijevod natpisa po čitanju koje smo predložili glasi: Ovdje počiva Izak, sin Antiohov [iz ...]reande, u mjesecu Diju, 17. dana, za Herkulanova konzulata, 6. indikcije (17. listopada 452.). Upotrijebljen je sirijsko-makedonski mjesec Dios, što indicira istočnjačko porijeklo pokojnika (Izakov natpis je drugi u ranokršćanskoj epigrafiji Dalmacije koji se ne ravna po julijanskom kalendaru). Na makedonski kalendar ukazuje i inverzni poredak brojki u danu unutar mjeseca (dodatan indicij pokojnikova porijekla). Indikcionalno datiranje u Dalmaciji je snažno zastupljeno od početka V. do kraja VI. st., ali izvan salonitanske regije je rijetko: van nje sačuvana su samo tri natpisa s takvom vremenskom odrednicom - u Trogiru, Šibeniku (porijeklom iz Ridera) te Anastazijev natpis u Slanom. Utoliko je lopudski nalaz jedinstven, jer predstavlja tek četvrti primjer tog načina datiranja u dalmatinskoj epigrafiji izvan provincijske metropole, a prvi van nje koji je na grčkom jeziku. Uz dataciju, precizirana je indikcija (šesta indikcija, od 1. rujna 452. do 31. kolovoza 453.) i konzulat (Flavije Bas Herkulan, od 1. siječnja do 31. prosinca 452.). Šesta indikcija i Herkulanov konzulat preklapaju se u rujnu, listopadu, studenom i prosincu 452. Događaj je svrstan i pod točnom indikcijom i pod točnim konzulatom. Izakova smrt i sahrana odigrala se, prema tome, u intervalu između 1. rujna i 31. prosinca 452., što je dodatno potvrđeno danom i mjesecom uklesanim na natpisu. Razriješen je podatak natpisa o porijeklu pokojnika (naselje sufiksa -reanda, u sjevernoj Siriji ili Maloj Aziji). 
Anastazijev i Izakov grobni spomenik su ne samo prostorno (Slano je smješteno u od Lopuda 10 -ak km zračne linije udaljenoj uvali, nasuprot Šipanu), nego i vremenski bliski (Anastazijev je natpis nepunih deset godina mlađi od Izakova). Pripadao je skupnom nalazu sarkofagâ i zidanih grobnica (svojevrsnom grobnom recinktu) za koji se pretpostavlja da je nastao u ovisnosti o ranokršćanskoj crkvi čiji se ostaci naslućuju ispod sadašnjeg franjevačkog samostana Sv. Jeronima iz XV. i XVI. stoljeća. ${ }^{10}$ Istom crkvenom objektu - ili nekoj njegovoj sukcesivnoj fazi - pripadala je osmerokutna krstionica s četverolisnim krsnim zdencem pronađena sjeverno od samostanske crkve (nalazi nisu objavljeni). Baptisterij se datira u VI. stoljeće, dok bi sâma crkva mogla biti ranija. ${ }^{11}$

Sred pročelja sanduka slanskoga sarkofaga je tabula ansata dvočlane profilacije (u ansama su isklesani reljefni latinski križevi proširenih svršetaka krakova, sl. 1a-b) koju ispunjava epigrafičko polje (1.09 x $0.46 \mathrm{~m}$ ) sljedećega teksta:

${ }^{10}$ Grobni spomenici pronađeni su slučajno, poljskim radovima u proljeće 1901., nedaleko od zapadnog oboda franjevačkog samostana, na lokalitetu mikrotoponima »U Polju« ili »U Peći za kućom«. Otkrivena četiri sarkofaga i dvije zidane grobnice pokrivene kamenim pločama nalazili su se na dubini cca. 1,5 m, u četvrtastoj udubini površine cca. $23,52 \mathrm{~m}^{2}$, sa sjeverne strane omeđenoj zidom, dok su ostaci zida slične strukture utvrđeni i na južnom te istočnom rubu jame. Unutar tako definiranog grobnog areala (zapadni nastavak nije istražen) svi su ukopi bili pravilno pozicionirani uzduž zidova, poredani tako da respektiraju jedni druge i perimetar grobne zone. Usp. Bulić (1901b): 196, gdje je i skica iskopane sonde. Anastazijev sarkofag (na Bulićevom tlocrtu br. 4) ležao je po sredini sjevernog dijela ograđenog prostora, uzdužnih stranica usporednih sa sjevernim zidom.

${ }^{11}$ Krstionicu u literaturi prvi spominje Fisković (1980): 254, bilj. 54 (po saopćenju Dubravke Beritić). Za pregled dosadašnjih arheoloških istraživanja i literature o cijelom lokalitetu v. Chevalier (1995): 458-460 i Vučić (2012): 94-95, 149-151, 238-239 (katalog kamene plastike). Vučić (2012): 150-151 spominje moguću stariju, manju krstionicu istovjetnog oblika na istom mjestu. Posljednji su o lokalitetu pisali PekovićBabić (2016): 167-168, donoseći opširan pregled starije, mahom arheološke literature (vrlo sažeta preliminarna priopćenja u arheološkim godišnjacima i drugim publikacijama). Potpuno objavljivanje nalaza iz arheoloških istraživanja 1974., 1986.-1990. i 2007.-2008. još uvijek se očekuje. Temeljem tih, neobjavljenih nalaza, Peković i Babić iznose i hipotezu o ranokršćanskoj crkvi pod sjevernim dijelom klaustra i zapadnim dijelom lađe postojeće samostanske crkve. Predlažu rekonstrukciju jednobrodne crkve T-tlocrta sa slobodnostojećom polukružnom apsidom čije tjeme tangira ravni začelni zid. Čitavu konstrukciju dovode u vezu s već spomenutom krstionicom te ih pozicioniraju unutar pretpostavljenog kasnoantičkog kastruma. U tom kontekstu autori raspravljaju i o kronologiji okolnog groblja, ističući da »natpis na sarkofagu prezbitera Anastazija neupitno dokazuje da je na ovome lokalitetu 462. godine već postojala kršćanska nekropola«. Na koncu iznose smionu pretpostavku da sakralno zdanje u Slanom treba pripisati graditeljskoj aktivnosti Istočnih Gota u Dalmaciji (493.-535.). Utemeljenost svih ovih zaključaka moći će se procijeniti tek nakon publiciranja rezultata starih odn. provođenja novih istraživanja, na osnovi egzaktnih arheoloških pokazatelja. Posavec (2007) začudo ne spominje Anastazijev sarkofag (iako cijelo jedno poglavlje posvećuje nadgrobnoj plastici, arhitekturi, spomenicima i natpisima V. stoljeća u Dalmaciji). 
$D(e) p$ (ositio) et requies $s(a n) c(t) i$ ac venera(ndi) / Anastasi pr(es)b(yteri) d(epositus) VId(us) Mart(ias) / indict(ione) XV post $c$ (on) s(ulatum) Severini $v$ (iri) $c{\text { (larissimi })^{12}}^{12}$

Ukop i počivalište svetog i poštovanog svećenika Anastazija. Položen 5. dana prije Martovskih Ida, 15. indikcije, poslije konzulata Severina, prejasnog muža.
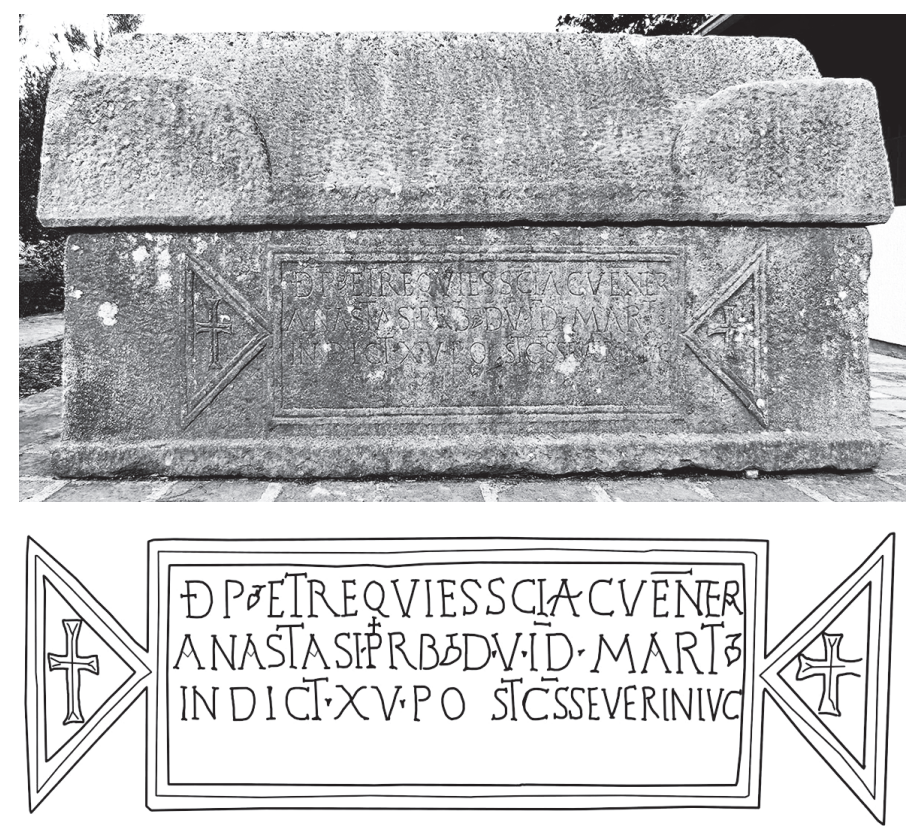

Sl. 1a-b. Slano, franjevački samostan Sv. Jeronima, lapidarij, sarkofag svećenika Anastazija (foto: Nada Bruer Ljubišić; crtež: Vučić 2012, 264)

Anastazijev nadgrobni natpis datiran je 11. ožujka 462. godine, za vrijeme petnaeste indikcije, postkonzulatom Severina, konzula Zapadnog Rimskog Carstva za prethodnu, 461. godinu. Kronologijski sustav sastoji se od datacijskih formula izraženih indikcionalnim i konzularnim

${ }^{12}$ CIL III, $14623=$ ILCV $1174=$ AE 1902, 208. Bulić je dvaput objavio integralnu verziju svoga članka (Bulić 1901a i Bulić 1901b), a tekst natpisa su prema potonjoj zatim R. Cagnat i M. Besnier prenijeli u Année épigraphique (godište za 1902., tiskano 1903.) te E. Diehl u Inscriptiones Latinae Christianae veteres. Jedina razlika između dviju verzija Bulićeva rada je uvodni dio u Bulić 1901a, posvećen antičkoj topografiji dubrovačkog primorja i lokaliziranju Slanog unutar njega (po Bulićevu mišljenju Slano je istovjetno naselju Pardua). Po Bulićevim člancima epitaf su u Corpus inscriptionum Latinarum objavili Th. Mommsen, O. Hirschfeld i A. Domaszewski. Čitanje u Zeiller (1906): 130 neznatno se razlikuje u prvoj i devetoj riječi: Dep(ositio) et requies s(an)c(t)i ac venera(ndi) / Anastasi pr(es)b(yteri)d(ie) VId(us) Mart(ias) / indict(ione) $X V$ post c(on)s(ulatum) Severini v(iri) c(larissimi). Crtež natpisa nesebično nam je ustupio kolega Jakov Vučić, na čemu mu zahvaljujemo, kao i Nadi Bruer Ljubišić te kolegi Ivanu Viđenu koji su izradili fotografije sarkofaga. 
datiranjem, te danom u mjesecu prema rimskom kalendarskom sustavu. ${ }^{13}$ Leksik epitafa čvrsto je usidren u tradiciju sepulkralne epigrafije antičkog i ranokršćanskog doba, uglavnom standardnih izraza i formulacija. ${ }^{14}$ Bulićeva, Diehlova i Zeillerova čitanja obogatila su natpis samo ponekim novim detaljem ili nijansom, no bitno novih tumačenja smisla i sadržaja natpisa ipak nije bilo. Ni ovom prilikom, što se teksta tiče, neće biti novih dopuna ili promjena, jer sam natpis ne donosi nikakve nejasnoće u čitanju. S druge strane, jedan dio natpisa može se na drugi način interpretirati, što ćemo ovdje učiniti. Pažnju donekle privlači udvajanje početnog apelativa za Anastazijevo grobno mjesto - depositio et requies. Oboje su zapravo generički nazivi za grob, u upotrebi naročito u kasnoantičko doba, no u sadržajnom smislu riječi oni su gotovo sinonimi (»ukop« $\mathrm{i} »$ počivalište «). ${ }^{15}$ Indikcionalno datiranje u Dalmaciji je snažno zastupljeno od početka V. do kraja VI. stoljeća, ali izvan salonitanske regije je rijetko: van nje sačuvana su samo tri natpisa s takvom vremenskom odrednicom - uz slanski epitaf, to su nadgrobni natpisi iz Trogira, Šibenika (spolij porijeklom iz Danila-Ridera) te Lopuda. ${ }^{16}$ Slanski sarkofag i njegov natpis istraživani su s tipološke i ikonografske točke gledišta, ${ }^{1 \dagger}$ odnosno u kontekstu proučavanja uloge slanskog primorja u prostornoj organizaciji ranokršćanskog doba, ${ }^{18}$ ali prozopografija Anastazijeva epitafa nije istraživana, niti je uočena važnost ovog natpisa za konzularne datacije kao epigrafski pokazatelj političke pripadnosti Dalmacije u kasnoantičko-ranokršćanskom razdoblju.

Uslijed koncentracije na salonitansku epigrafiju, naime, donekle su ostali zapostavljeni natpisi iz drugih krajeva kasnoantičke Dalmacije, naročito ukoliko se radilo o nalazima iz ruralnih, vangradskih područja, i inače slabije istraživanih. Do sada su za proučavanje problema

${ }^{13}$ Bulić (1901b): 202-203 i Zeiller (1906): 131 uočavaju zapadnorimskog konzula istog imena i 482., točno primjećujući da se 15 . indikcija može odnositi samo na starijeg Severina.

${ }^{14}$ Za paleografski opis v. Bulić (1901b): 198-199. Latinski pokraćeni epitet u genitivu vē̄era može se razriješiti kao venerabilis ili venerandi. Bulić (1901b): 199 se opredijelio za potonji, u čemu su ga slijedili svi kasniji izdavači (CIL III 14623 dvoji između venera(ndi) i venera(bilis)). Bulić (1901b): 199-201 i Zeiller (1906): 131 opširno raspravljaju o značenju pojma sanctus u epigrafici, zaključujući da se ovdje radi o počasnom atributu često pridavanom pripadnicima klera u ranokršćanskom razdoblju, bez stvarnih obilježja svetosti u smislu crkvenog kulta.

${ }^{15}$ Kako je primijetio već Bulić (1901b): 199.

${ }^{16}$ Marin (1994): 72, 74; Marin (2010); Marin (2013b): 177. Navedeni natpisi su CIL III, 2704, 9706 = ILS 8256 = ILCV 3834 (Trogir, moguće V. st.) i ILCV $376=$ ILJug 3, 2799 (Šibenik-Rider, kraj V. ili VI. st.).

${ }^{17}$ Fisković (1980): 242-243; Cambi (2002): 49, 53. Usp. pregled literature u Vučić (2012): 267, koji sarkofag uspoređuje sa salonitanskim grčkim epitafom iz 450. (Salona IV-2: 1153-1155, br. 772). Uvršten je i u repertorij ranokršćanskih sarkofaga Dalmacije: Dresken-Weiland (1998): 109, No. 310 i Taf. 101, 3 (s pogrešnom datacijom u 461. godinu); usp. također Koch (2000): 96, 106, 554. Slanski sarkofag spominje i Nikolajević (1965): 466 kao lokalni rad.

${ }^{18}$ Fisković (1980): 242-243; Zaninović (1993): 142. 
vrhovne vlasti nad kasnoantičkom Dalmacijom korišteni isključivo konzularni natpisi iz Salone, ${ }^{19}$ dok su ostali - pa tako i onaj Anastazijev - ostali u prikrajku istraživačkog interesa. Međutim, onog časa kada utvrdimo da i on - sretnom koincidencijom - pripada natpisima nastalima u razdoblju bilateralnog ignoriranja konzula obaju Carstava, taj epigrafski spomenik postaje prvorazrednim izvorom za izučavanje navedenoga pitanja.

Naime, slanski epitaf datiran je, kako je gore navedeno, postkonzulatom Severina, zapadnorimskog konzula za prethodeću, 461. godinu. Godine 462. zapadnorimski konzul Libije Sever i istočnorimski konzul Lav I. nisu se međusobno priznavali: prethodni zapadni car Majorijan koji je imao potporu Konstantinopola - svrgnut je 2. kolovoza, a umoren 7. kolovoza 461., poslije čega je Libije Sever proglašen augustom (19. studenog 461.) kao marioneta svemoćnog patricija i magistra militum Ricimera. Lav I. nije Libija Severa priznao ni za augusta, ni za konzula. S druge strane, Sever je Lava »priznao« kao augusta, ali ne i kao konzula za 462 . godinu. U skladu s tim, na zapadnim natpisima što se odnose na 462. godinu jedini konzul je Libije Sever, ${ }^{20}$ no ovo u Dalmaciji izgleda nije bio slučaj. Anastazijev natpis, naime, nije datiran ni Severom ni Lavom. Prethodne, pak, 461. godine zapadni konzul Flavije Severin i istočni konzul Flavije Dagalaif isprva se nisu uzajamno priznali, ali je krajem godine istočni dvor priznao zapadnog konzula. Zato se Severin naknadno javlja u istočnim postkonzularnim datacijama, npr. na papirusu od 20. rujna 462. s grčkom inačicom latinske formule p.c. Fll. Dagalaifi et Severini vv. cc.). Nasuprot tome, zapadni dvor istočnog konzula Dagalaifa ni tada, ni poslije nije priznao. ${ }^{21}$

Zašto je na slanskom epitafu pred aktualnim konzulima za 462 . dana prednost postkonzulatu zapadnog tipa iz 461. godine? Prema Buliću, konzulat Libija Severa izbjegnut je u dataciji Anastazijeva natpisa zato što je tadašnji stvarni gospodar Dalmacije, vojskovođa Marcelin, nakon prijeke smrti zapadnorimskog cara Majorijana 461. odbio poslušnost njegovom nasljedniku - Libiju Severu - i politički se približio istočnorimskom caru Lavu I. (ali, čini se, nije formalno priznao njegovu

${ }^{19}$ Marin (2013a): 170-175 oslonio se na dosad najtemeljitije proučenu epigrafsku dokumentaciju, zaključivši na temelju konzularnih datacija da je Dalmacija kontinuirano stajala pod zapadnorimskom upravom; s njegovim smo zaključkom u cijelosti suglasni. Usp. komentar u Basić-Zeman (2017).

${ }^{20}$ CLRE (1987): 458, 459. Pošto su Severovi natpisi malobrojni (ukupno ih je šest, svi potječu iz Italije, od čega samo jedan izvan Rima), nema dovoljnog statističkog uzorka da bismo doznali kada je najranije novost o njegovu konzulatu mogla prispjeti u ostale pokrajine. Ipak je indikativno da je natpis iz Eklana (današnji Mirabella Eclano jugoistočno od Beneventa) od 15. svibnja 462. datiran po njegovu konzulatu (CIL IX, $1373=$ ILCV 3028a = ICI 8, 41).

${ }^{21}$ CLRE (1987): 457. Za papirus iz 462. godine v. bilj. 35. Da su se oba konzula 461. uzajamno odbila priznati, primjećuje već Bulić (1901b): 202, s osloncem na De Rossija. 
vrhovnu vlast). Stoga, po Buliću, slanski natpis nije datiran ni istočnim ni zapadnim konzulom. ${ }^{22}$

Nakon Bulića, jedini koji je ozbiljnije pristupio tom problemu bio je Jacques Zeiller. Autor je, nadovezujući se na Bulićeva razmišljanja, ponudio vrlo široko povijesno objašnjenje izostanka konzulâ za 462 . godinu na slanskom natpisu. Po Zeilleru, natpis u Slanom datiran je postkonzulatom Severina, zapadnog konzula za 461. godinu - umjesto konzulatom zapadnog cara Libija Severa za 462. - zato što je zapadnorimski car Majorijan svrgnut još 2. kolovoza 461., potom umoren 7. kolovoza iste godine, a njegova nasljednika, Ricimerova kandidata Libija Severa (imenovanog tek 19. studenog 461.), nije priznalo ni Istočno Rimsko Carstvo, niti dalmatinski vlastodržac, patricij Marcelin (454.468.). S druge strane, istočni konzul za 462. godinu bio je car Lav I., čiji konzulat na Zapadu nije bio priznat iz istih razloga. Zato, po Zeillerovu mišljenju, nije čudno što je sa slanskog natpisa izostavljen Libije Sever, samoproglašeni zapadni konzul za 462. godinu, čije je preuzimanje carske i konzulske titule istočni dvor smatrao dvostruko nelegitimnim. ${ }^{23}$ Natpis se nalazio na dalmatinskom teritoriju, pod kontrolom istočnorimskog štićenika Marcelina, a ovaj nije priznavao Libija Severa kao zapadnorimskog cara; dosljedno tome, Severov konzulat za 462. godinu u Dalmaciji je bio ništetan.

Zeillerovo je mišljenje, međutim, bitno obilježeno njegovim stanovištem da je Dalmacija 437. godine odstupljena Istočnom Rimskom Carstvu. Ukoliko se ono odbaci kao neosnovano, ${ }^{24}$ automatski otpada $i$ potreba da Severinov postkonzulat na slanskom natpisu tumačimo onako kako je to činio Zeiller. Uostalom, autor uopće nije postavio pitanje zašto na Anastazijevu natpisu - ako je njegova, Zeillerova, interpretacija točna - nema Istočnjaka Dagalaifa kao drugog konzula? Sasvim je, doduše, moguće da Marcelinova uprava zbilja nije smatrala Libija Severa legitimnim konzulom (čime Bulićeva i Zeillerova hipoteza o Marcelinovu odbijanju Severova legitimiteta dobiva na plauzibilnosti), no pitanje zašto je umjesto njega retrospektivno odabran prethodni zapadni konzul nauštrb istočnog ostalo je netaknutim u literaturi. Po čemu bi u postkonzularnoj formuli legitimitet Severina kao konzula za 461. imao prvenstvo pred legitimitetom Dagalaifa, istočnog konzula u toj istoj godini, i to u navodno istočnorimskoj pokrajini? Drugačije rečeno: zašto bi u Marcelinovoj Dalmaciji (navodno pod istočnom upravom od 454.)

${ }^{22}$ Bulić (1901b): 203-204. Izdavači u CIL III 14623, kako se čini, ne shvaćaju u potpunosti Bulićevo objašnjenje odsustva Lavova konzulata, jer postuliraju da se Marcelin pobunio protiv Lava I.

${ }^{23}$ Zeiller (1906): 130, 131. Razlika između Bulićeva i Zeillerova shvaćanja je prvenstveno u tome što Bulić smatra da je Dalmacija sve do 461. godine službeno pripadala Zapadnom Rimskom Carstvu, dok francuski povjesnik drži da je odstupljena Istočnom Rimskom Carstvu još 437. godine.

${ }^{24}$ Za punu argumentaciju v. Basić-Zeman (2017): passim. Usp. također Basić (2017). Posljednji su o problemu raspravljali Gračanin (2011): 71-72, Marin (2013a) i Gračanin (2015): 13, 21. 
uopće zapadni konzul bio na prvom mjestu u dataciji? Na slanskom natpisu očekivalo bi se datiranje po Fl. Dagalaifu (konzulu 461.) ili Lavu I. (konzulu 462.). ${ }^{25}$ Moguće je, naravno, i da je izostanak istočnog konzula na Anastazijevu natpisu uzrokovan jednostavnim kašnjenjem informacija: do ožujka 462. godine u Dalmaciju iz Konstantinopola možda još nije bila pristigla informacija o Lavovu konzulatu; ali i u tom slučaju svejedno ostaje začudnim i neobjašnjenim zašto je - u nedostatku imena novog istočnog konzula - za datacijsku formulu odabran postkonzulat zapadnog konzula, i to isključivo njega. Da je Dalmacija tada zaista stajala pod upravom Istočnog Carstva, na natpisu bi se očekivao istočni tip datacije tj. postkonzulat Dagalaifa, ili eventualno obojice konzula s istočnim konzulom Dagalaifom na prvom mjestu. Okolnost što se u tekstu Anastazijeva epitafa nije tako postupilo treba, dakle, objasniti na drugi način.

Odmah na početku valja odbaciti pretpostavke da se u Dalmaciji u ožujku 462. godine nije znalo tko je bio drugi, istočni konzul za prethodnu godinu. ${ }^{26}$ On, Flavije Dagalaif, epigrafski je potvrđen kao eponimni konzul na jednom natpisu iz Soluna već u 461. godini (Sl. 2):

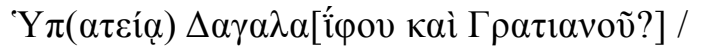

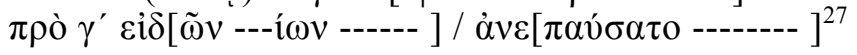

$$
\begin{aligned}
& \text { Za konzulata Dagalaifa [i Gracijana?], } \\
& \text { tri dana prije [...] ih Ida, umro je [...] }
\end{aligned}
$$

Teško je vjerovati da se u Solunu 461. znalo točno ime tekućeg eponimnog konzula, a u Slanom se još u ožujku 462. godine to ime ne bi znalo (naročito ako je Dalmacija pod upravom Istočnog Carstva koje je Dagalaifa i nominiralo), sve i ako dozvolimo vrlo dugotrajno kašnjenje diseminacije konzulova imena. No, čak i ukoliko ostavimo po strani solunski natpis (pošto je isti veoma fragmentaran, pri čemu identifikacija Dagalaifa s konzulom iz 461. nije posve neprijeporna: Denis Feissel

${ }^{25}$ Gauthier (2010): 66 ispravno konstatira da svi dalmatinski natpisi iz vremena Marcelinove vladavine (454.-468.) imaju zapadni tip datacije, osim jednog (koji nije presudan jer se radi o konzulu-carskom rođaku, v. bilj. 29). Slično i Marin (2013a): 173.

${ }^{26}$ Kao primjer koliko su imena konzula mogla kasniti u Salonu (čak i kad nije bilo unilateralnog ili bilateralnog nepriznavanja konzulskih nominacija) može poslužiti konzulat ili postkonzulat Aecija i Studija na grčkom epitafu jednog Istočnjaka iz kolovoza 454. ili kolovoza 455. godine. Obojicu konzula nominirao je istočnorimski dvor, te su u istom poretku navođeni u objema polovicama Carstva - Salona IV-2: 11551157, br. 773. Ukoliko je riječ o postkonzulatu (kako epigrafski tekst restituira CLRE (1987): 442, te stoga natpis datiraju u kolovoz 455.), to bi značilo da konzuli za 454. godinu u Saloni još nisu bili poznati u kolovozu iduće godine. Latinski natpis s epitafom izvjesnog Marcelijana (Salona IV-1: 480-481, br. 211) u svakom slučaju potvrđuje da njihova imena nisu u Saloni bila diseminirana ni do 1. ožujka 454. godine, jer je ovaj datiran zapadnorimskim postkonzulatom Opilija.

${ }^{27}$ IG X, 2, 1, 776; Feissel (1983b): 123-124, br. 128. Upitnik ovdje postavljen uz restituirani dio teksta rezultat je dvojbi oko redoslijeda kojim su konzuli navedeni, pa i samog njihovog broja (jedan ili dvojica?), što ovdje izravno utječe na dataciju natpisa (v. bilj. 28 i 29). 
ga, primjerice, poistovjećuje s istoimenim konzulom iz 366., ${ }^{28}$ mada Roger S. Bagnall, Alan Cameron, Seth R. Schwartz i Klaas A. Worp u svom studioznom kompendiju kasnorimskih konzula nisu prihvatili Feisselovu dataciju solunskog konzularnog natpisa, već su se opredijelili za Dagalaifa iz 461. godine, što je i po našem mišljenju vjerojatnije: na natpisima, naime, datiranim konzulatom civila i člana carske obitelji, osoba carskog porijekla automatski ima prednost prvenstva, $\mathrm{i}$ to neovisno o dijelu Carstva), ${ }^{29}$ druga dva prvorazredna epi-

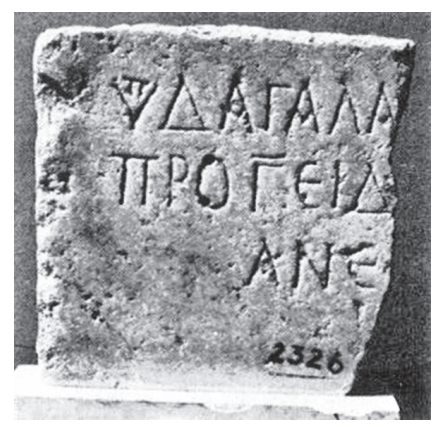

S1. 2. Solun, nadgrobni natpis nepoznatog pokojnika (Feissel 1983b, Pl. XXVII)

${ }^{28}$ Feissel (1983b): 123-124, br. 128. Istoimeni konzuli obnašali su dužnost 366., 461. i 506. godine. Feissel se odlučio za konzula Dagalaifa iz 366. godine iz dva razloga: zato što se formula konzularne datacije nalazi na početku natpisa (što je po autoru specifikum grčkih natpisa na Zapadu od 352.-405.), i jer je Gracijan mogao biti naveden na drugom mjestu u dataciji zato što je proglašen mlađim augustom Zapada istom 367. (ali autor upozorava i na jedan papirus iz 366. gdje je Gracijan naveden na prvom mjestu). Ovakvu identifikaciju konzula prihvaća i Habicht (1974): 490. Nasuprot tome, Bagnall (1981-1982): 183 smatra da IG X, 2, 1, 776 pripada konzulatu Dagalaifa iz 461., što argumentira činjenicom da je Gracijan bio sin cara Valentinijana I. (a osobe carskog porijekla su u pravilu u konzularnim datacijama uvijek imale primat pred privatnim osobama). Iako 366. još nije bio august (proglašen 24. kolovoza 367.), kao najstariji sin vladajućeg cara, kao član carske obitelji i kao designirani nasljednik trona, Gracijan je imao višestruki primat na natpisima spram svoga konzulskog sudruga (v. bilj. 29).

${ }^{29}$ CLRE (1987): 680. Redoslijed u konzulskim parovima bio je podređen strogim pravilima prvenstva: ukoliko je jedan od konzula bio car, a drugi civil, car je bio naveden na prvom mjestu; ukoliko su oba konzula bili carevi, august je imao prednost pred cezarom; ukoliko su oba konzula bili u rangu augusta, prvenstvo u redoslijedu je imao stariji august; u slučaju da su konzuli bili civili, primat je imao konzul koji je već prije obnašao tu čast; careva rodbina ili svojta nominirana za konzula također je imala prvenstvo pred konzulom koji nije bio u srodstvu s carem. U svim ostalim slučajevima prvenstvo u redoslijedu konzulâ određivao je car-senior. Od 411. godine sve razlike među konzulima-civilima su dokinute: svaka je polovica Carstva na prvom mjestu navodila svog konzula (ova se novost prvi put javlja 421., a redovita je od 432.). Usp. CLRE (1987): 22. S druge strane, pravila o primatu careva i članova carske obitelji nastavila su se provoditi i nakon 411 . godine po principu senioriteta.

Ozbiljan prigovor identifikaciji Dagalaifa sa solunskog natpisa s konzulom iz 366. nalazi se u činjenici što je Gracijan konstantno navođen kao prvi konzul u svoj poznatoj dokumentaciji za 366. godinu: konzularnim popisima (fasti consulares), zakonodavnim aktima, natpisima (15 natpisa iz Rima i 4 iz ostatka Italije), papirusima i drugim tekstualnim vrelima (historiografska i literarna djela), i to u oba partes Imperii. Osim toga, Gracijan je, iako tek sedmogodišnji dječak, istodobno s nastupom konzulata primio titulu nobilissimus puer, u praksi rezerviranu za službenog prijestolonasljednika, što dodatno umanjuje mogućnost da bi u datacijskim formulama bio drugonavedeni konzul, sekundaran Dagalaifu. Usp. evidenciju u CLRE (1987): 266-267, čemu treba dodati natpis AE 1955, 52 = AE 1973, 581 iz Aradija u Prokonzularnoj Africi: Eminentissimo s(a)eculo / ddd(ominorum) nnn(ostrorum) Valentinia/no Valenti Gratia/no n(obilissimo) p(uero) semper AAA(u)ggg(ustis); v. također Lenski (2002): 90; McEvoy 
grafska spomenika osporavaju hipotezu da ime konzula Dagalaifa nije bilo na vrijeme divulgirano da bi pravodobno stiglo do Slanog u Dalmaciji.

Riječ je o dva epitafa na grčkom jeziku u samostanu Alahan (Koja Kalessi) u Izauriji na jugoistoku Male Azije, na periferiji Cilicije. Prvi natpis uklesan je na grobu u jednoj od spilja nedaleko od samostana (Sl. 3):

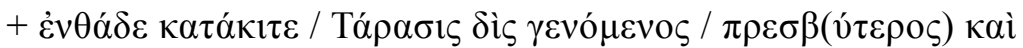

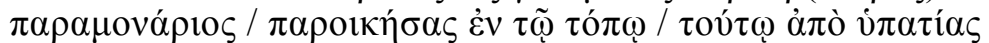

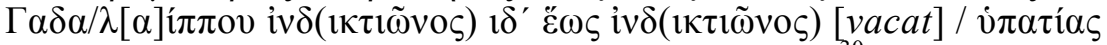

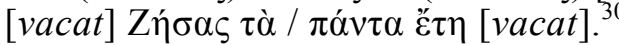

+ Ovdje počiva Tarazije Mlađi, koji je bio svećenik i paramonarij, službovavši na ovom mjestu od Dagalaifova konzulata, četrnaeste indikcije, do [---] indikcije, [---] konzulata. Živio je ukupno [---] godina.

U neposrednoj blizini prvoga uklesan je i drugi natpis, dio epigrafičkog teksta unutar tabulae ansatae na pročelju monumentalnog sarkofaga (Sl. 4):

(2013): 49. Bilo bi krajnje neobično da se postupilo drugačije jedino na solunskom natpisu. Gracijanovo eksplicitno uključivanje u carski kolegij na afričkom natpisu ukazivalo bi da je već 366. smatran augustom ravnopravnim ostaloj dvojici (usp. sintagmu semper AAA(u)ggg(ustis)), što isključuje teoriju o njegovu nižem rangu na solunskom natpisu. Nadalje, prema AE 1973, 581 kratica NP na afričkom natpisu odnosi se isključivo na Gracijana i ima se razriješiti n(obilissimo) p(uero). Gracijan je s tom titulom potvrđen u mnogim konzularnim datacijama iz 366. godine, i to u obliku: Gratiano n(obilissimo) p(uero) et Dagalaifo conss(ulibus) (pet puta u Codex Theodosianus, jednom u Codex Justinianus). Odstupanje od te i takve prakse značilo bi da je Gracijan na solunskom natpisu premješten na drugo mjesto konzulskog para, i da je ispuštena njegova titula.

Za srodan slučaj s članovima carske obitelji usp. salonitanski natpis od 1. ožujka 466., datiran postkonzulatom Baziliska i Hermenerika (Salona IV-1: 483-484, br. 213). Oba su konzula proklamirana na Istoku, a Bazilisk je k tome bio šurjak Lava I.; usprkos Baziliskovu srodstvu s carskom obitelji, na Zapadu je u tekstovima natpisâ 465. godine Hermenerik navođen kao consul prior, ali ne i u Dalmaciji, gdje Bazilisk ima prvenstvo. S druge strane, Bazilisk je 465. godine navođen na prvom mjestu u istočnim konzularnim fastima, dijelu zapadnih, u Liber Pontificalis, zakonima sačuvanim u Codex Justinianus te u pismima pape Hilarija (461.-468.). Moguće je da je Baziliskov primat naknadno proglašen - usp. CLRE (1987): 18, bilj. 56 i 464-465, gdje je ostavljena i mogućnost da se radi o konzulatu. Na ovaj natpis upozorava Marin (2013a): 171 točno zaključujući da predstavlja zapadni tip konzularne datacije. Vidi i Gauthier (2010): 66.

${ }^{30}$ SEG XIV, 813 = SEG XXXVI, 1223; Gough (1955): 116. Lakune u posljednja tri retka trebale su biti naknadno ispunjene podacima o Tarazijevoj dobi, konzulu i indikciji u vrijeme njegove smrti, što se nije dogodilo. Nekoliko Goughovih sitnijih pravopisnih i interpunkcijskih previda u restituciji ovdje je popravljeno. Važna stavka $\mathrm{u}$ formuli datacije jest prostor ostavljen za ime konzula u pretposljednjem retku: očigledno je bio predviđen samo jedan konzul (zasigurno istočnorimski), što dosad nije primijećeno. Na uvijek dobrodošlim kolegijalnim savjetima oko grčkog teksta zahvalni smo Milenku Lončaru. 


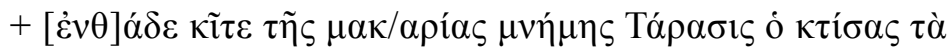

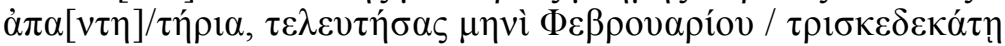

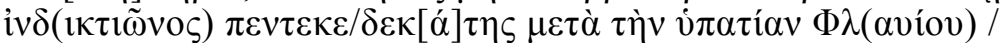

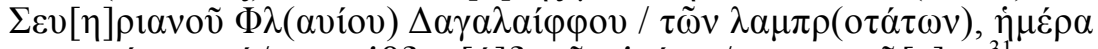

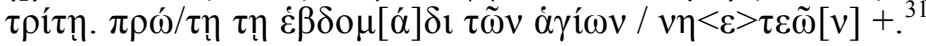

+ Ovdje počiva blažene uspomene Tarazije, utemeljitelj gostinjca, umrijevši trinaestoga dana mjeseca veljače, petnaeste indikcije, poslije konzulata Flavija Severina i Flavija Dagalaifa, prejasnih muževa, trećega dana, prvoga tjedna svete korizme.

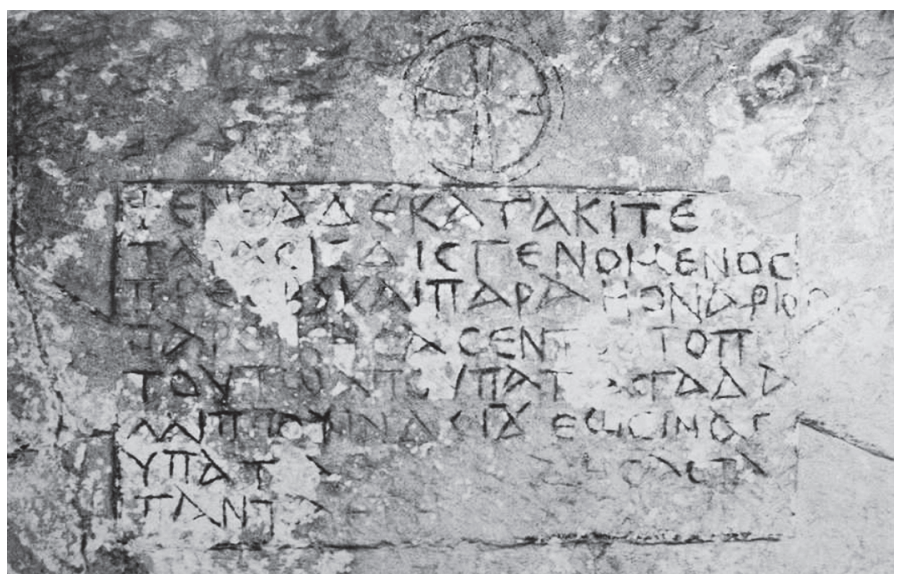

S1. 3. Alahan, nadgrobni natpis Tarazija Mlađeg (Gough 1955, Pl. IX c)

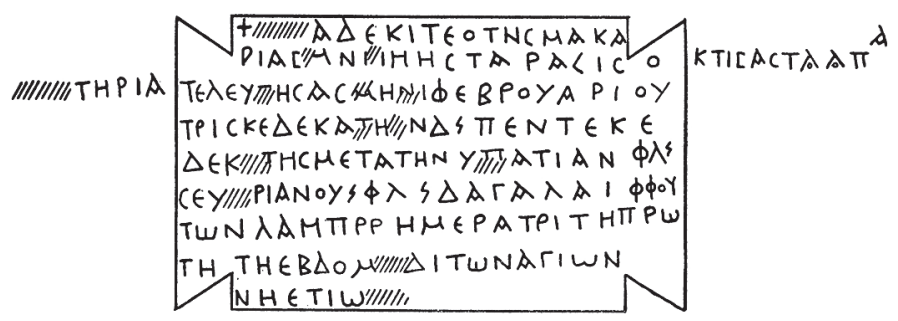

Sl. 4. Alahan, nadgrobni natpis Tarazija Starijeg (Gough 1955, 116, fig. 1)

Oba natpisa su nadgrobnog karaktera, i pripadala su vjerojatno istoj osobi, monahu Taraziju čija je prvobitna grobnica naknadno zamijenjena novom (prema drugim mišljenjima, radilo se o dva monaha istog imena, možda ocu i sinu, koji su preminuli u kratkom vremenskom

${ }^{31}$ CIG IV, $9259=$ SEG XIV, $812=$ SEG XXXVI, 1222. Natpis je prvi objavio De Laborde (1847): 175, otkuda ga je Boeckh prenio u Corpus inscriptionum Graecarum. Točniji prijepis i čitanje tiskani su uz komentar u Headlam (1892): 24-25, a završne poboljšice u Gough (1955): 116. O sarkofagu Tarazija Ml. usp. Koch (2000): 96, 106, 568. Goughova restitucija natpisa ovdje je unekoliko korigirana (neznatni pravopisni previdi). 
razmaku) ${ }^{32}$ Oba epitafa su vremenski određena i indikcionalnom i konzularnom datacijom (mlađi natpis dodatno i danom u mjesecu te danom u tjednu i vjerskom svetkovinom): stariji je natpis datiran četrnaestom indikcijom te konzulom Flavijem Dagalaifom (čije je ime pogrešno navedeno u obliku $\Gamma \alpha \delta \alpha \lambda i \pi \pi 0 \varsigma$ ) što znači da je natpis sastavljen između siječnja i kolovoza 461. godine. Drugi je natpis datiran 13. veljače, petnaestom indikcijom te postkonzulatom Flavija Severina i Flavija Dagalaifa (ovdje je ime istočnog konzula ispravno navedeno, ali je ime njegovoga zapadnog sudruga deformirano u »Severijan«). Kasniji je natpis, prema tome, višestruko precizno vremenski određen u 13 . veljače 462. godine, čemu je pridodana informacija o danu u tjednu (utorak) i korizmenom postu. Između nastanka prvog i drugog izaurijskog natpisa proteklo je, dakle, minimalno šest, maksimalno trinaest mjeseci. To, drugim riječima, znači da stariji Tarazijev natpis prethodi Anastazijevu natpisu iz Slanog za 7 do 14 mjeseci, dočim je mlađi Tarazijev natpis načinjen samo 27 dana prije slanskog epitafa. Oba izaurijska natpisa, kako je navedeno, datirana su istočnim konzulom Dagalaifom (mlađi i zapadnim, Severinom). Uzevši sve navedene podatke u obzir - a neovisno o solunskom natpisu - začuđujuće je i krajnje neuvjerljivo da bi u zabačenoj Ciliciji najranije u siječnju ili najkasnije u kolovozu 461. godine sastavljaču natpisa bilo poznato ime tekućeg konzula, a u Dalmaciji naredne godine navodno ne. ${ }^{33}$

${ }^{32}$ Headlam (1892): 24-25 zastupao je gledište o dvojici monaha, Taraziju Starijem i Taraziju Mlađem, koji su umrli jedan nedugo nakon drugoga, te pokopani u neposrednoj blizini. Gough (1955): 116-117 i bilj. 4 isprva je smatrao da je riječ o jednoj te istoj osobi s dvije grobnice, da bi kasnije promijenio mišljenje te prihvatio moguće postojanje dva različita Tarazija - Gough (1967): 37, 38, 43, 45. Da se doista radilo o dvojici Tarazija, ukazuje natpis sa srebrnog relikvijara iz sredine V. st. pronađenog u Çirgi, 50-ak km jugozapadno od Alahana (sada u Arheološkom muzeju u Adani): vi $\pi \dot{\varepsilon} \rho$

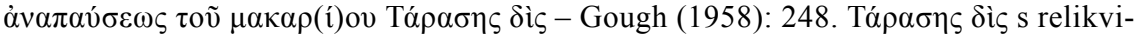

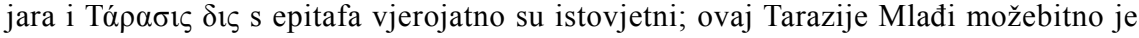
umro i sahranjen izvan Alahana, što bi objasnilo zašto kronološki podaci na njegovu nadgrobnom natpisu nikad nisu uneseni. Ovakvu identifikaciju prihvaća Grabar (1962): 57; odbija je Feissel (1984): 564-565, bilj. 105 koji ime dedikanta s relikvijara čita kao Tarasikodissa (pandan izvornom imenu cara Zenona) s osloncem na Buschhausena. Šire o relikvijaru: Noga-Banai (2008): 159-160, kat. 10.

${ }^{33}$ Iako to nipošto nije (i ne može biti) odlučujući argument, treba naglasiti da je samostanska crkva u Alahanu (Koja Kalessi, Alahan Kilise) - gdje su oba natpisa uklesana u okolnim liticama - smještena na vrlo izoliranom i teško pristupačnom mjestu, u planinama Izaurije, na više od $1200 \mathrm{~m}$ nadmorske visine i preko $900 \mathrm{~m}$ iznad doline rijeke Kalikadnos. Premda se dobre veze s prijestolnicom mogu pretpostaviti za vladavine cara Zenona (474.-491.), porijeklom Izaurijca, koji se i osobno angažirao oko kompleksa u Alahanu, Tarazijevi natpisi za više od desetljeća prethode tim poboljšanim komunikacijama. Oba natpisa važna su kao terminus ante quem za početak gradnje crkvenog kompleksa (gostinjac u natpisu Tarazija St. zasigurno nije podignut prije same crkve). Čitav sklop se u početku datiralo u Justinijanovo vrijeme - usp. Forsyth (1957): 233 - da bi potom istraživači sve više preferirali dataciju u posljednju četvrtinu V. st., naročito pod utjecajem radova M. Gougha (1972: 209-210) i sinteze R. Krautheimera (1986: 108-109, 245-247, gdje autor kronološki razdvaja dvije crkve u Alahanu, datiravši zapadnu u treću četvrtinu V. st., a istočnu u kraj V. ili početak VI. st.). 
Isto što vrijedi za natpis Tarazija Mlađeg iz 461., vrijedi a fortiori za natpis Tarazija Starijeg iz 462. godine. Taj epitaf, datiran 13. veljače 462. godine, nastao nepunih mjesec dana prije teksta na Anastazijevu sarkofagu u Slanom, nosi sličnu postkonzularnu dataciju kao njegov dalmatinski pandan: postkonzulat Severina i Dagalaifa (ovdje je iznimno u poretku konzulâ privilegiran onaj zapadni, iako se radi o istočnorimskom teritoriju). ${ }^{34}$ Epitaf Tarazija Starijeg vjerno zrcali istočnorimsko priznavanje zapadnog konzula Severina potkraj 461. godine, koje je onda u Alahanu dosljedno primijenjeno povodom smrti svećenika Tarazija u veljači iduće, 462. godine. Kako je već navedeno, Dagalaif usprkos tomu nije priznat na Zapadu, što je u krajnjoj liniji i uzrok razlici izaurijskog i slanskog natpisa. U oba navrata, dakle, i u prvoj polovini 461. i u veljači 462., u Izauriji je ime konzula za 461. godinu, Dagalaifa, bilo itekako dobro poznato. Ta je informacija najkasnije u rujnu 462. godine dospjela i u Egipat (inače provinciju u koju su takve vijesti redovito dolazile zadnje, u pravilu s velikim zakašnjenjem), jer tamošnji papirus datiran 20. rujna 462. također rabi formulu postkonzulata Da-

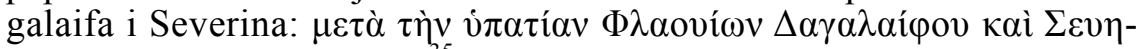
pívov $\tau \tilde{\omega} v \lambda \alpha \mu \pi \rho(o \tau \alpha ́ \tau \omega v) .{ }^{35}$ Prema tome, pouzdano je utvrđeno:

- da se za ime istočnorimskog konzula Dagalaifa iz 461. u Izauriji znalo već u prvih osam mjeseci te godine (a izgledno je i da solunski natpis s Dagalaifovim imenom potječe iz 461.);

- da se imena obojice konzula iz 461., Severina i Dagalaifa, u maloazijskim pokrajinama Istočnog Carstva znalo u veljači 462. (Izaurija);

- da se imena obojice konzula iz 461., Severina i Dagalaifa, u udaljenim pokrajinama Istočnog Carstva znalo u rujnu 462. (Egipat);

U svemu, dakle, tvrdnja da u Slanom u ožujku 462. autori natpisa tobože ne bi raspolagali Dagalaifovim imenom već jedino Severinovim

Elton (2002): 155-156 potpuno negira Zenonovu ulogu u izgradnji Alahana jer objekti kompleksa ne dostižu monumentalne dimenzije i razinu raskoši drugih investicija tog vladara u Izauriji i drugdje. Za potpuni pregled literature o tom pitanju v. Kosiński (2010): 636-637, koji je sklon Goughovoj dataciji za Zenonove vladavine (s prekidom u izgradnji nakon careve smrti 491.).

${ }^{34}$ Redoslijed konzula na mlađem natpisu iz Alahana vrlo je neobičan: čak i nakon što je istočni dvor priznao Severinov konzulat na Zapadu iz 461., krajnje je neuobičajeno da $\mathrm{u}$ formuli datacije $\mathrm{s}$ istočnorimskog teritorija zapadni konzul zauzme prvo mjesto (usp. CLRE (1987): 459: »The order of names in the Isaurian inscription is remarkable «). Razloge takvom povlađivanju Zapadu je teško dokučiti; vjerojatno se radilo o pokušaju diplomatskog približavanja drugoj polovini Carstva u promijenjenim političkim okolnostima, ili naprosto o pogrešci klesara. Postkonzulat je upotrijebljen možda zato što vijest o konzulatu Lava I. za 462. u veljači nije još dospjela u Alahan (u Egipat nije dospjela još ni u rujnu, v.d.). Gough (1955): 118 konstatira da su preferirani prošlogodišnji konzuli, ali ne nudi objašnjenje.

${ }^{35}$ PSI III 175.1. Usp. CLRE (1987): 459. Svakako je zanimljivo da je papirus P. Oxy. 724913 od 2. prosinca 462. ispravno datiran drugim konzulatom cara Lava I.:

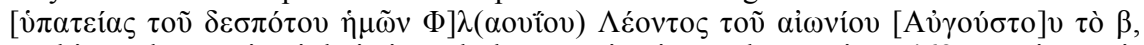
što bi moglo upućivati da je između konca rujna i početka prosinca 462. u Egipat prispjela vijest o aktualnom konzulu za tu godinu. 
- postaje neodrživa. Preostaje zaključiti da na natpisu u Slanom nedostaje ime istočnog konzula Dagalaifa jednostavno zato što ga Zapadno Carstvo nikada nije priznalo.

Dagalaif se nikad ne pojavljuje na zapadnim natpisima. Severin je kontinuirano jedini konzul na natpisima iz Rima (5 natpisa), Italije (4 natpisa) i Germanije (1 natpis); rimski natpisi s kalendarski preciznim datumom raspoređeni su unutar 461. godine od 3. svibnja do 23. srpnja, italski natpisi od 25. siječnja do 9. studenog, a za germanski natpis je predložena datacija 22. travnja. ${ }^{36}$ Imajući na umu vremenski raspon tih natpisa od siječnja sve do studenog, to su nedvojbena svjedočanstva da je na Zapadu kroz cijelu 461. godinu Severin smatran jedinim konzulom (što je u skladu sa saznanjima iz inih izvora koji potvrđuju da Dagalaifa zapadni dvor nikad nije priznao, dočim je Severin koncem godine ipak priznat na Istoku). Isto važi i za južnu Dalmaciju u kojoj se nalazi Slano, tj. tadašnje naronitansko-epidaursko primorje: ondje je Severinovim postkonzulatom datiran Anastazijev nadgrobni natpis jer se provincija nalazila pod suverenitetom zapadnog dijela Carstva. Samim time za Dagalaifa na slanskom epitafu nije bilo mjesta.

Zaokružujući ovdje iznesena razmatranja, svakako valja istaknuti i ustanoviti da još jedan epigrafski spomenik iz Dalmacije predstavlja moguću potvrdu onoga što je dosad izloženo. To je salonitanski natpis iz 463. godine - jednu godinu, dakle, mlađi od slanskog natpisa - datiran zapadnim konzulom Flavijem Cecinom Decijem Bazilijem: + Hic $d[$ eposita - - ] / inl(ustris) f(emina) d(ie) [- - Bas]/ilio v(iro) [c(larissimo) cons(ule)]. ${ }^{37}$ Ignoriran je istočni konzul Flavije Vivijan. Prema dostupnoj evidenciji, Bazilijev konzulat nikad nije diseminiran u Egiptu, vjerojatno ni uopće na Istoku (što je naročito razvidno na papirusima s postkonzularnom datacijom), dok Vivijanov konzulat zauzvrat po načelu recipročnosti nije diseminiran na Zapadu (papinska pisma i italski natpisi datirani su isključivo po Baziliju). ${ }^{38} \mathrm{U}$ skladu s navedenim, zapadni tip konzularne datacije na salonitanskom epitafu nepoznate pokojnice iz 463., unatoč fragmentarnoj očuvanosti, dodatno je epigrafičko svjedočanstvo pripadnosti provincije zapadnome suverenitetu, zajedno s lopudskim natpisom iz 452. i slanskim iz 462. godine.

Najuvjerljivijim i najjednostavnijim objašnjenjem ostaje da su u Dalmaciji u ožujku 462. godine epigrafski spomenici - poput sarkofaga svećenika Anastazija - datirani postkonzulatom zapadnog tipa jer je ta pokrajina tada bila pod upravom pars Occidentis.

${ }^{36}$ CLRE (1987): 456, 680. O Dagalaifu sintezno v. PLRE (1980): 340: s.v. Fl. Dagalaiphus 2; o Severinu: PLRE (1980): 1001, s.v. Fl. Severinus 5.

${ }^{37}$ Salona IV-1: 482-483, br. 212. Tako natpis shvaća i tumači Marin (2013a): 171, što treba bezuvjetno podržati. Usp. također CLRE (1987): 460.

${ }^{38}$ CLRE (1987): 461. 


\section{BIBLIOGRAFIJA}

Bagnall, R. S. 1981-1982: The Prosopography of the Later Roman Empire, Volume 2: A.D. 395-527 by J. R. Martindale. - Classical Journal, 77, fasc. 2, 183-184.

Basić, I. 2017: Dalmatiae, Dalmatiarum: a study in historical geography of the Adriatic (in the light of the new inscription from Córdoba). - In: Illyrica antiqua II: $o b$ honorem Duje Rendić-Miočević. International conference, Šibenik, $12^{\text {th }}-15^{\text {th }}$ September 2013. Ed. Demicheli, D., Zagreb, 309-333.

Basić, I., Zeman, M. 2017: In partibus Occidentis. Izakov epitaf s Lopuda i pitanje vrhovne vlasti nad Dalmacijom u V. stoljeću. - Starohrvatska prosvjeta, ser. III, 44, u tisku.

Bulić, F. 1901a: Necropoli antica cristiana a Slano di Ragusa. - Bullettino di archeologia e storia dalmata, XXIV, 85-99.

Bulić, F. 1901b: Necropoli antica cristiana a Slano di Ragusa. - Nuovo bullettino di archeologia cristiana, VII, 195-204.

Bury, J. B. 1923: History of the Later Roman Empire from the Death of Theodosius I to the Death of Justinian (A.D. 395 to A.D. 565). Vol. I. London.

Cambi, N. 2002: Sarcofagi con la croce nel centro della cassa. - In: Akten des Symposiums »Frühchristliche Sarkophage«, Marburg, 30. 6.-4. 7. 1999. Ed. Koch, G., Mainz am Rhein, 47-56.

Chevalier, P. 1995: Ecclesiae Dalmatiae. L'architecture paleochrétienne de la province romaine de Dalmatie (IV ${ }^{\mathrm{e}}$-VII ${ }^{\mathrm{e}} \mathrm{S}$.) en dehors de la capitale, Salona. Tom. 1-2. Rome-Split.

CLRE 1987: Bagnall, R. S., Cameron, A., Schwartz, S. R., Worp, K. A. - Consuls of the Later Roman Empire. [Philological Monographs of the American Philological Association, 36]. Atlanta.

De Laborde, L. 1847: Église d'Aladja dans le Taurus (inscription grecque inédite). Revue archéologique, IV, fasc. 1, 172-176.

Dresken-Weiland, J. 1998: Repertorium der christlich-antiken Sarkophage, Bd. 2. Italien mit einem Nachtrag Rom und Ostia, Dalmatien, Museen der Welt. Mainz am Rhein.

Elton, H. 2002: Alahan and Zeno. - Anatolian Studies, 52, 153-157.

Feissel, D. 1983a: Notes d'épigraphie chrétienne (VI). - Bulletin de correspondance hellénique, 107, fasc. 1, 601-618.

Feissel, D. 1983b: Recueil des inscriptions chrétiennes de Macédoine du $\mathrm{III}^{\mathrm{e}}$ au $\mathrm{VI}^{\mathrm{e}}$ siècle. [Bulletin de correspondance hellénique, Suppl. VIII]. Athènes.

Feissel, D. 1984: Notes d'épigraphie chrétienne (VII). - Bulletin de correspondance hellénique, 108 , fasc. 1, 545-579.

Feissel, D. 2010: Formules funéraires grecques. - In: Salona IV-1, 38-39.

Fisković, I. 1980: O ranokršćanskim spomenicima naronitanskog primorja. - Izdanja Hrvatskog arheološkog društva, 5, 213-256.

Forsyth, G. H. 1957: Architectural Notes on a Trip Through Cilicia. - Dumbarton Oaks Papers, 11, 223-236.

Gauthier, N. 2010: L'empereur et la cité. - In: Salona IV-1, 64-66.

Gough, M. 1955: Some recent finds at Alahan (Koja Kalessi). - Anatolian Studies, 5, 115-123.

Gough, M. 1958: A fifth century silver reliquary from Isauria. - Byzantinoslavica, 19, 244-250.

Gough, M. 1967: Alahan Monastery: Fourth Preliminary Report. - Anatolian Studies, 17, 37-47.

Gough, M. 1972: The Emperor Zeno and Some Cilician Churches. - Anatolian Studies, 22, 199-212.

Grabar, A. 1962: Un reliquaire provenant d'Isaurie. - Cahiers archéologiques, XIII, 4959. 
Gračanin, H. 2011: Južna Panonija u kasnoj antici i ranom srednjovjekovlju (od konca 4. do konca 11. stoljeća). Zagreb.

Gračanin, H. 2015: Kraj antike na hrvatskim prostorima. - In: Nova zraka u europskom svjetlu: Hrvatske zemlje u ranome srednjem vijeku (oko 550 - oko 1150) [Povijest Hrvata, I]. Ed. Nikolić Jakus, Z., Zagreb, 3-36.

Habicht, Ch. 1974: Inscriptiones Graecae. Vol. X: Epirus, Macedonia, Thracia, Scythia. Pars II: Inscriptiones Macedoniae. Fasc. 1: Inscriptiones Thessalonicae et viciniae ed. Carolus Edson. - Gnomon, 46, fasc. 5, 484-492.

Headlam, A. C. 1892: Ecclesiastical sites in Isauria (Cilicia Trachea) [The Society for the Promotion of Hellenic Studies, Supplementary Papers, 1]. London.

Koch, G. 2000: Frühchristliche Sarkophage. München.

Kosiński, R. 2010: The Emperor Zeno's Church Donations. - In: Hortus historiae. Księga pamiątkowa ku czci Profesora Józefa Wolskiego w setną rocznicę urodzin. Ed. Dąbrowa, E., Dzielska, M., Salamon, M., Sprawski, S., Kraków, 635-649.

Krautheimer, R. 1986: Early Christian and Byzantine Architecture. Harmondsworth.

Lenski, N. 2002: Failure of Empire: Valens and the Roman State in the Fourth Century A.D. Berkeley-Los Angeles-London.

Ljubić, Š. 1875: O upraviteljih Dalmacije za rimskoga vladanja. - Rad Jugoslavenske akademije znanosti i umjetnosti, 31, 1-68.

Marin, E. 1994: Civitas splendida Salona. - In: Salona Christiana. Ed. Marin, E., Split, 9-104.

Marin, E. 2010: Datations indictionneles. - In: Salona IV-1, 107-108.

Marin, E. 2013a: Natpisi ne pokazuju da bi Dalmacija bila ustupljena Istočnorimskom Carstvu 437. godine, već da je u okviru Zapada sve do Justinijanova osvajanja. - In: Moji rimski papiri (2004-2011). Zagreb, 164-175.

Marin, E. 2013b: Indikcionalne datacije. - In: Moji rimski papiri (2004-2011). Zagreb, 176-178.

McEvoy, M. A. 2013: Child Emperor Rule in the Late Roman West, AD 367-455. Oxford.

Meimaris, Y. E., Kritikakou, K., Bougia, P. 1992: Chronological systems in RomanByzantine Palestine and Arabia. The evidence of the dated Greek inscriptions. Athens.

Nikolajević, I. 1965: La décoration architecturale des églises découvertes à DoljaniMonténégro. - In: Atti del VI Congresso internazionale di archeologia cristiana (Ravenna, 23-30 settembre 1962). Città del Vaticano, 457-470.

Noga-Banai, G. 2008: The Trophies of the Martyrs. An Art Historical Study of Early Christian Silver Reliquaries. Oxford.

PLRE 1980: The Prosopography of the Later Roman Empire. Vol. II (A.D. 395-527). Ed. Martindale, J. R., Cambridge.

Peković, Ž., Babić, K. 2016: Kasnoantička sakralna arhitektura u doba Istočnih Gota u Dalmaciji. - Prostor, 24, fasc. 2 (52), 156-171.

Posavec, V. 2007: Dalmacija u vrijeme Marcelina i Julija Nepota. Split.

PSI: Papiri greci e latini. Pubblicazioni della Società Italiana per la ricerca dei papiri greci e latini in Egitto. Vol. I-XVI. Ed. Vitelli, G., Norsa, M. Firenze.

Rogošić, R. 1962: Veliki Ilirik (284-395) i njegova konačna dioba (396-437). Kritična istraživanja Ilirika iz kasnije povijesti Rimskog Carstva. Zagreb.

Salona IV: 1-2: Salona IV. Inscriptions de Salone chrétienne, IVe-VII ${ }^{\mathrm{e}}$ siècles. Vol. 12. Ed. Gauthier, N., Marin, E., Prévot, F., Rome.

Vučić, J. 2012: Topografija Naronitanske biskupije. Doktorska disertacija, Filozofski fakultet, Zagreb.

Wilkes, J. J. 1972: A Pannonian refugee of quality at Salona. - Phoenix, 26, fasc. 4, 377-393. 
Zaninović, M. 1993: Ranokršćanske crkve kao postaje plovnoga puta duž istočnog Jadrana. - Vjesnik za arheologiju i historiju dalmatinsku, 86, 125-146.

Zeiller, J. 1906: Les origines chrétiénnes dans la province romaine de Dalmatie. Paris.

\section{SUMMARY}

\section{POSTCONSULATE AND PARS IMPERII ON THE INSCRIPTION OF PRESBYTER ANASTASIUS FROM SLANO (AD CIL III 14623)}

The Latin inscription on the sarcophagus of presbyter Anastasius from Slano in the vicinity of Dubrovnik (Croatia) (CIL III, $14623=$ ILCV $1174=$ AE 1902, 208) is dated in three ways: by day and month of the year (fifth day before the Ides of March = 11 March), by indiction (15th indiction, 1 September 461-31 August 462), and by postconsulate of Flavius Severinus (1 January-31 December 461). The date is 11 March 462. The prosopography of Anastasius' epitaph was never thorougly studied, nor was the consular dating of this inscription used as an epigraphic indication for the partitio Imperii in 5th-century Illyricum. The present paper establishes that the said inscription belongs to one of the years when the consuls of both partes Imperii did not recognize each other. The postconsular dating is of a Western type (consul of Western Roman Empire for the previous year); the Eastern consul for 461 (Dagalaiphus), as well as Western and Eastern consuls for 462 (Libius Severus and Leo I) are both ignored. This, in conjunction with three inscriptions from the territory of Eastern Roman Empire - one from Thessaloniki (IG X, 2, 1, 776) and two from Alahan in Isauria (SEG XIV, 813 = SEG XXXVI, 1223; CIG IV, $9259=$ SEG XIV, $812=$ SEG XXXVI, 1222) - and other sources, points to the conclusion that the name of Eastern consul for 461, Dagalaiphus, was not unknown in Dalmatia in 462. This in turn goes to show that the name of Dagalaiphus was intentionally omitted from Anastasius' epitaph in favor of the Western consul, i.e. that the province of Dalmatia in 462 recognized only the sovereignty of Western Roman Empire. Inscription of presbyter Anastasius, therefore, may serve as epigraphic evidence that the supposed donation of Dalmatia to the Eastern Roman Empire by Galla Placidia in 437 did not take effect; Dalmatia, apparently, formally remained under Western administration. 
